\title{
Gender inequality in education: Political institutions or culture and religion?
}

\author{
Arusha Cooray ${ }^{\mathrm{a}, \mathrm{b}, *}$, Niklas Potrafke $^{\mathrm{c}}$ \\ a School of Economics, University of Wollongong, NSW, 2522, Australia \\ b Centre for Applied Macroeconomic Analysis, Australian National University, Canberra, ACT, 0200, Australia \\ c Department of Economics, University of Konstanz, D-78457 Konstanz, Germany
}

\section{A R T I C L E I N F O}

\section{Article history:}

Received 27 February 2010

Received in revised form 20 August 2010

Accepted 30 August 2010

Available online 16 September 2010

\section{JEL classification:}

011

015

043

057

P26

P36

$\mathrm{Z} 12$

Keywords:

Gender discrimination

Education

Democracy

Religion

\begin{abstract}
A B S T R A C T
We investigate empirically whether political institutions or culture and religion underlie gender inequality in education. The dataset contains up to 157 countries over the 1991-2006 period. The results indicate that political institutions do not significantly influence education of girls: autocratic regimes do not discriminate against girls in denying educational opportunities and democracies do not discriminate by gender when providing educational opportunities. The primary influence on gender inequality in education is through culture and religion. Discrimination against girls is especially pronounced in Muslim dominated countries.
\end{abstract}

(c) 2010 Elsevier B.V. All rights reserved.

\section{Introduction}

Education or human capital is a prominent positive influence on economic growth and development. In particular, educating girls increases human capital and growth (Schultz, 1994; Knowles et al., 2002; Klasen, 2002; Dollar and Gatti, 1999). Educating girls is doubly advantageous. As with males, increased human capital of females directly increases incomes and growth; however, there is a further benefit of educating girls because of the positive influence of mothers on the education and health of their children (Schultz, 2002; Doepke and Tertilt, 2009).

Education of girls is therefore important for economic development because of the human-capital transmission through mothers. ${ }^{1}$ However, political elites in autocratically ruled societies have incentives not to encourage education and investment in human capital because economic development will give rise to a middle class that will seek democratic institutions and accountability from government (Bourguignon and Verdier, 2000; Welzman, 2010). ${ }^{2}$ If education of girls is in particular conducive

\footnotetext{
* Corresponding author. School of Economics, University of Wollongong, NSW, 2522, Australia. Tel.: +6124221 4017.

E-mail address: arusha@uow.edu.au (A. Cooray).

1 One of the United Nations Millennium Development Goals (MDGs) is to eliminate gender inequality in education at the primary and secondary levels (United Nations, 2008). However, the goal does not appear to be on-track for attainment.

2 See Hillman (2007) for an overview of the incentives of non-democratic governments not to provide quality free-access education.
} 
to economic development, self-preservation of political elites in non-democratic societies is a suggested explanation for gender bias against girls in education in government schools. ${ }^{3}$

An investigation of the reasons for gender inequality in education should therefore consider the role of political institutions. ${ }^{4}$ An alternative hypothesis is that culture and religion determine attitudes to education of girls. For example, a report on democratization in Afghanistan (Larson, 2009) states that:

"Afghanistan is not democratic due to the lack of these key factors: Is this a democracy, when girls can't go to school to read, when violence against girls takes place in many provinces like Kandahar and Faryab? When acid is spread on the faces of girls, where is democracy? When girls are poisoned in the schools of Parwan how we can say that we have democracy?

The respondent was here referring to a series of incidents across the country in which acid has been thrown at schoolgirls by extremists ideologically opposed to girls' education. In Parwan province in May 2009 there were reports of toxic gas being dispersed in girls' school playgrounds by fundamentalist groups also." (Larson, 2009: 13).

\section{Prior studies}

Prior studies have provided mixed empirical evidence regarding the influence of democracy on gender equality in education. Brown (2004) used the data of Barro and Lee (1993) on educational attainment, with the dependent variable the average number of years women attended school divided by the average number of years that men attended school in 1990 . Democracy was measured by the sub-indicators of POLITY III; the independent variables were mean values for each country between 1960 and 1990; and the sample consisted of 105 high and low-income countries. The results suggest that only an executive-recruitment sub-component of democracy had a positive influence on gender equality in education. ${ }^{5}$

Beer (2009) investigated the relation between gender equality and political regimes and found the unexpected result that democracy may negatively influence gender equality in educational attainment. Her dependent variable for gender equality in education was the difference between the average years of educational attainment of women and men. Democracy was measured by the level and stock of the POLITY IV democracy indices, as well as the year in which women gained the right to vote. The sample consisted of 179 developed and low-income countries between 1960 and 2004. She concluded that countries with longer-term democracy and longer duration of women's suffrage had higher proportions of female to male life expectancy, lower fertility rates, and higher labour force participation rates, due to the ability of women to advance their interests through voting. However, both the stock of democracy and the year in which women gained suffrage had a negative influence on gender equality in education, so contradicting a hypothesized positive relationship between democracy and gender equality in education. Her results are sensitive to the inclusion of an illiteracy variable, exclusion of which made the democracy variable positive (Beer, 2009, p. 224).

Empirical evidence from prior studies on the influence of religion on gender equality in education is likewise unambiguous. Norton and Tomal (2009) used the data of Barro and Lee (1993) on educational attainment to show that religion has influenced gender equality in education. The dependent variable was the log-odds ratio of female educational attainment and the log-odds ratio of the gender gap (absolute differences between male and female percentages for four levels of educational attainment). Religion was measured by the share of the population that is Buddhist, ethno-religious, Hindu, Muslim, Orthodox, Protestant or Roman Catholic (data by Barrett et al., 2001). The sample consisted of 97 high and low-income countries. The results suggested that the proportion of Hindu and Muslim adherents in a country has a negative influence on female educational attainment.

Becker and Woessmann (2008) used country and town-level data from the first Prussian census of 1816 to show that Protestantism had a positive influence on gender equality in primary education. The dependent variable was the female enrolment share in public primary school (county data) and in public and private primary and secondary school (town data).

\section{The present study}

The empirical strategies of the above studies on democracy and gender equality have shortcomings that we have aimed to correct. We depart from the previous studies in three ways. First, we use the new Democracy-Dictatorship (DD) variables from

\footnotetext{
${ }^{3}$ Government does not in general have a monopoly on schooling. Private provision of education is however usually small relative to public provision. In lowincome countries, private schools are for the elites, whose children are also often sent abroad for education. In reaction to the inadequacies of governmentprovided schooling for the general population in low-income countries, there have also been self-financed user-price schools for children of poor families. Hillman and Jenkner (2004) describe how parents in low-income countries have circumvented low-quality or absent government education through user-pay schooling.

${ }^{4}$ With regard to possible reverse causation, previous studies have found that education has a positive influence on democracy (for example, Castelló-Climent, 2008; Barro, 1999; Glaeser et al., 2004; Papaioannou and Siourounis, 2008). Acemoglu et al. (2005) suggest, however, that after inclusion of fixed effects, there is no evidence that education enhances democracy. On the related causal relation between income and democracy, see Gundlach and Paldam (2009). Income distribution, which is itself politically determined, can influence public spending on education, in particular on different levels of education: Di Gioacchino and Sabani (2009) show that public education spending can give rise to persistent inequality if more unequal societies continue to spend more on higher levels of education than basic levels of education.

5 Time from initiation of suffrage has been used to study educational opportunities for women (Beer, 2009). We do not use this variable because of ambiguities in the relation between the right to vote and democracy. In numerous low-income countries, people have the right to vote, or indeed may be compelled to vote, but there is only one candidate for the position of president or other office.
} 
Cheibub et al. (2010) and the POLITY IV sub-indicator "Constraints on chief executive". Second, we use enrolment ratios disaggregated at the primary and secondary, and tertiary levels to measure gender inequality. Third, we focus on the recent past from 1991 to 2006 to investigate the relation between gender equality in education and a country's political institutions. We also juxtapose political institutions against cultural and religious influences. We measure the influence of culture and religion with dummy variables that take on the value one when a particular religion is dominant in a country. The data is from The Encyclopaedia of World Geography (1994) and the CIA World Factbook (2010). For robustness checks, we also employ the data on religion by Alesina et al. (2003). We find that political institutions do not matter for advancement of gender equality in education whereas culture and religion do.

In Section 4 we elaborate on the background for our empirical estimates. Section 5 presents the data and empirical strategy. Section 6 discusses the empirical results. Section 7 concludes.

\section{Background}

Democracy is expected to promote gender equality for several reasons. Women can better express their views and interests in democracies; democracies promote gender equality through an educated middle class; democratic governments spend on educating girls; income redistribution and public good provision in democracies reduce pressure on sons to take care of their parents in old age and illness (when parents expect their sons to take care of them in old age, incentives of a family to invest in the education of a son rather than in the education of a daughter increase); and men in democracies have a self-interest in educating their daughters. Democracy also facilitates gender equality through mobilization of women and electoral accountability (Beer, 2009, p.218): women can better organize to express their views and interests; they can obtain and disseminate information; and they may lobby for improving their status through education. Women may also be empowered to positions of leadership. Democracy also increases women's bargaining power within the household (Klasen and Wink, 2003), which can permit a mother to invest more in health and education of her children. The improved bargaining position of a mother can improve the bargaining position of a daughter in relation to a son-in-law (Doepke and Tertilt, 2009).

Democratic institutions are therefore conducive to gender equality, including in particular in education. In contrast, as noted, in countries with limited democracy rulers who seek to sustain political entrenchment are not interested in the development of an educated middle class and may discriminate against girls because of the important development role of educated mothers. ${ }^{6}$

Social norms affect gender equality. For example, with regard to labour-force participation, sons who are raised by a working mother tend to be more supportive of a working wife (Fernandez et al., 2004). In a similar vein, increased exposure to a female leader in every-day-life reduces the bias that males may have against supporting a female political leader. ${ }^{7}$ Norms can therefore promote equal educational opportunities for girls. ${ }^{8}$

However, religion and other aspects of culture, including compromise of ethical behaviour and the absence of the rule of law can inhibit education of girls (Dollar and Gatti, 1999; Inglehart and Baker, 2000; Hillman and Jenkner, 2004). Hillman (2004) has described Nietzschean behaviour as the strong being unconstrained by ethics in actions toward the weak. With women naturally physically weaker than men, women in Nietzschean societies are victims of male domination, which includes adverse discrimination against girls in schooling. If the role of the girl or woman is no more than to bear children and to provide satisfaction and services to males, education of girls may not enhance the perceived benefits to men, who are the "strong" and dominate the women, who are the "weak". Women can then also become objects to be purchased for use and traded (Di Tommaso et al., 2009). The uses to which women are subjected may therefore not require education. Indeed, education of girls can be an impediment to achieving the objectives through submission of women sought by men in Nietzschean societies. In particular, in the case of radical Islam, education of girls may be punishable by death, for the girls and for their teachers.

\section{Data and empirical strategy}

\subsection{Data}

We use data on enrolment ratios of boys and girls in education at the primary and secondary, and tertiary level, from the World Bank Development Indicators. Enrolments at the primary and secondary level are measured by one variable. The dataset contains up to 157 countries. We employ a cross-section for the year 2006. For some countries, most recent data are not available for 2006 but for 2005 or 2007. We in these cases use the data for 2005 or 2007 to include as many countries as possible.

The ratio of girls-and-boys in primary and secondary, and tertiary education differs across regions. An enrolment ratio of 1 indicates parity between females and males and deviations below (above) 1 can be interpreted as a degree of male (female) advantage on the enrolment measure. Girls are most underrepresented in South Asia and Africa. In Chad, for example, the

\footnotetext{
${ }^{6}$ Colonial regimes, on the other hand, often kept women disadvantaged. Women have disproportionally been employed in low-skilled agriculture, for example, in cash crops plantations (Adams, 2006). Brown (2000) describes the effects of colonization and democracy on enrolment for Middle Eastern, African, Asian, Central and South American countries. His results suggest that colonization decreased enrolment ratios in Sub-Saharan-Africa, despite a strong relationship between regime types and enrolment ratios in education.

7 Beaman et al. (2009) show that Indian villagers who have never experienced a female leader prefer male leaders. Exposure to a female leader weakens stereotypes about gender roles in the public and domestic spheres and eliminates negative bias in how female leaders' effectiveness is perceived among male villagers.

8 Indeed, the evidence is that girls take better advantage of educational entitlements than boys. For a summary, see Hillman (2009, chapter 8).
} 
enrolment ratio in primary and secondary education was 0.61 and in tertiary education 0.06 . Gender equality has been pronounced in Australia-Oceania, South-America and Central-Asia. In Uruguay and Mongolia, for example, the girls-and-boysenrolment ratio in primary and secondary education was 1.06 (both countries) and in tertiary education 1.68 and 1.56 on average respectively. In high-income countries and also former communist countries, gender equality in education was more common, which is reflected in girls-and-boys enrolment ratios in primary and secondary education around 1 with low variance.

Regional differences in education are often pronounced at the tertiary level: discrimination against girls is high in Africa (enrolment ratio 0.60 on average). Girls are overrepresented in the Middle East (enrolment ratio 1.54 on average) and South America (girl-and-boys enrolment ratio 1.36 on average).

In prior studies, the means of measurement of democracy have been the POLITY IV and the Freedom House indices. These indices have, however, been criticized on several grounds (Munck and Verkuilen, 2002; Vreeland, 2008; Cheibub et al., 2010). For example, Munck and Verkuilen (2002:28) conclude that Freedom House is an index "which [exemplifies] problems in all areas of conceptualization, measurement, and aggregation." The POLITY IV index has been criticized for similar reasons, but "the usefulness of the POLITY IV dataset lies in its components" (Cheibub et al., 2010: 76). The POLITY index has five components: XCONST (Constraints on chief executive), XRCOMP (Competiveness of executive recruitment), XROPEN (Openness of executive recruitment), PARCOMP (Competiveness of political participation), and PAREG (Regulation of political participation). In particular, the Chief Executive variable "provides useful information about whether the chief executive has unlimited authority, whether there is a legislature with slight or moderate ability to check the power of the executive, whether the legislature has substantial ability to check the executive, or whether the executive has parity with or is subordinate to the legislature" (Cheibub et al., 2010: 76). We employ the "Constraints on Chief Executive" variable as a democracy measure.

Cheibub et al. (2010) introduce a Democracy and Dictatorship (DD) measure of political regimes. The DD measure basically distinguishes between regimes in which executive and legislative offices are filled through contested elections and those in which they are not. The DD measure takes on the value 1 for democracies and 0 otherwise. Cheibub et al. (2010) provide a more encompassing discussion on classifying democracies and dictatorships.

To address reasonable concerns about reverse causality between democracy and gender equality in education, we relate gender equality in education in 2006 to the average of democracy over the 1991-2005 period. We focus on the period after 1991 because the DD measure is available for several countries only after that year. The variable "Constraints on chief executive" is not available for all years for every country. When missing data points for individual years occur, we take averages of the available years for the country.

Figs. 1 and 2 illustrate the association between the averaged XCONST and the DD democracy indices and the girls-and-boys enrolment ratios at the primary and secondary level respectively. Democracy and gender equality in education at the primary and secondary level are positively associated. In countries such as Afghanistan, Chad and Yemen, the girls-and-boys enrolment ratios as well as the democracy variables display low values. In Mongolia and the Dominican Republic, by contrast, gender equality at the primary and secondary level and democracy are advanced. We do not show the respective figures for the girls-and-boys enrolment ratios at the tertiary level and the XCONST and DD democracy indices. The positive relationship between gender equality at the tertiary level and democracy is somewhat less pronounced than the positive relationship between gender equality at the primary and secondary level and democracy.

We measure religion with dummy variables that take on the value one when a particular religion is dominant in a country. The information is from The Encyclopaedia of World Geography (1994) and the CIA World Factbook (2010). The religion variables are time-invariant. Both databases report for each country the same dominant religions. ${ }^{9}$ Measuring religion is much less controversial than measuring democracy. Muslim dominated countries are, for example, Afghanisthan, Iran, Iraq, Saudia Arabia. By contrast, OECD countries are dominated by Christianity.

Fig. 3 illustrates the association between Christianity and the girls-and-boys enrolment ratios at the primary and secondary level. Christianity and gender equality in education at the primary and secondary level are positively associated. By contrast, Fig. 4 shows that Islam and gender equality in education at the primary and secondary level are negatively associated. We do not show the respective figures for the girls-and-boys enrolment ratios at the tertiary level and the religion variables. The relationship between gender equality at the tertiary level and religion is less pronounced than the relationship between gender equality at the primary and secondary level and religion.

\subsection{Empirical strategy}

The base-line cross sectional model has the following form:

$$
E_{F M i}=\alpha+\beta \text { Democracy }_{i j}+\Sigma_{k} \delta \text { Religion }_{i k}+\Sigma_{l} \epsilon \text { Region }_{i l}+\Sigma_{m} \zeta x_{i m}+\eta \text { Colony }_{i}+u_{i}
$$

with $i=1, \ldots, 157 ; j=1,2 ; k=1, \ldots, 5 ; l=1, \ldots, 7 ; m=1, \ldots, 4$, where $E_{F M i}$ is the girls-and-boys enrolment ratio at the primary and secondary, and tertiary level for country $i$. Political institutions are indicated by the variable Democracy ${ }_{i j}$ which describes the two alternative democracy measures: the "Chief in Executive" variable and the Democracy-Dictatorship indicator respectively. We include one of the two democracy measures. $\Sigma_{k} \delta$ Religion $_{i k}$ describes the set of religion dummy variables. These take on the value

\footnotetext{
${ }^{9}$ The three main sources of the Encyclopaedia of World Geography (1994) are: Britannica World Data (Encyclopaedia Britannica Inc, Chicago annual); Stateman's Yearbook, Keesings Record of World Events (Keesings Redhill updated throughout the year), The data relate to the years 1993 and 1994 . The data of the CIA World Factbook (2010) relate to the year 2010.
} 


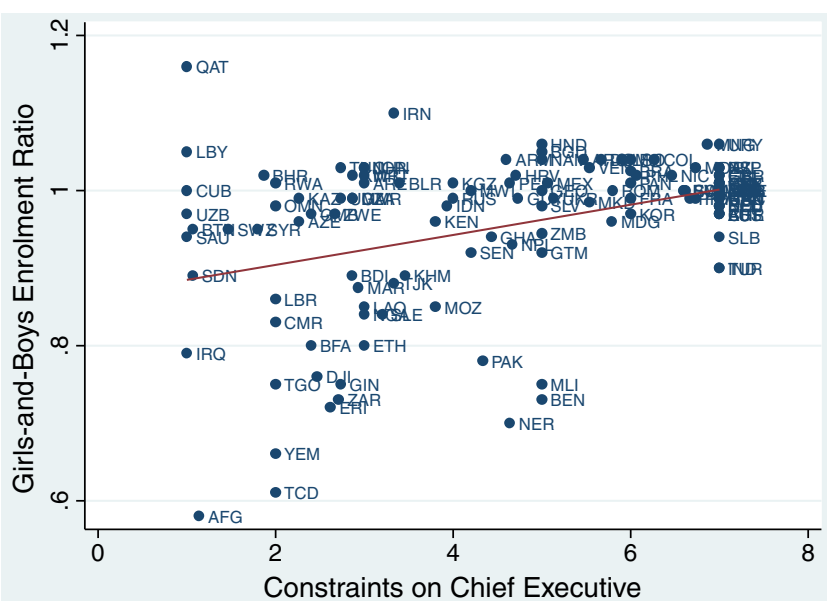

Fig. 1. Girls-and-boys enrolment ratio in primary and secondary education (2006) and POLITY IV Chief of Executive Democracy Index (average 1991-2005). Source: World Bank (2010) and Marshall and Jaggers (2006).

of one when a particular religion is dominant and zero otherwise (see, for example, Dollar and Gatti, 1999; Inglehart and Baker, 2000). We distinguish five religions: Christianity, Buddhism, Islam, Hinduism and Indigenous Religion. Our reference category is Christianity. ${ }^{10}$ Protestantism led, for example, to better education (Becker and Woessmann, 2009, 2010) and greater gender equality in education (Becker and Woessmann, 2008). The proportion of Hindu and Muslim adherents in a country has been shown to have a negative influence on female educational attainment (Norton and Tomal, 2009). We therefore expect negative influences of the religion dummies on gender equality in education compared to the reference category of Christianity. $\Sigma_{l} \epsilon$ Region ${ }_{i l}$ describes a set of regional dummy variables, which take on the value of one when a country is in a particular region and zero otherwise. We distinguish eight different regions: Africa, Asia, the Middle East, South America and the West Indies, North America, Eastern Europe and Central Asia, Western Europe and Australia-Oceania. To avoid multicollinearity between the region dummies, one of the region dummies functions as the reference category (here Africa). The estimated effects of the other region dummies are then interpreted as deviations from the reference category. Colony $y_{i}$ describes a dummy variable that takes on the value one when the respective country was a British or French colony and zero otherwise. We expect a negative influence of the colony variable on the girls-and-boys enrolment ratios in education. ${ }^{11}$ The vector $x_{i}$ contains our political-economic control variables. Following the related studies on democracy and education, we include the logarithm of real GDP per capita (Dollar and Gatti, 1999; Klasen, 2002).

Gender equality in education is expected to increase with real GDP per capita. We also include trade openness (as a share of GDP). The predicted influence of trade-openness on gender equality on education is ambiguous. Higher trade openness could decrease gender equality because in several developing countries unskilled females have been employed in labour intensive export industries (e.g., Cagaty and Ozler, 1995; Fontana and Wood, 2000; Baliamoune-Lutz and McGillivray, 2007). By contrast, higher trade openness could also increase gender equality because trade openness is expected to narrow the wage gap between skilled and unskilled workers and men and women. Higher relative wages may give women access to educational opportunities.

We also include government expenditures as a share of GDP as a proxy for public spending on education. Encompassing data on public spending on education are not available. The predicted influence of government expenditures on gender equality on education is ambiguous. Higher government expenditures could decrease gender equality in education because educating girls could be especially promoted. A greater government budget does however not necessarily imply a higher share of education expenditure.

We also include the logarithm of total population to control for country size. Female employment in agriculture (as a share of total employment) is not available, however, for the entire sample. Including female employment in agriculture significantly reduces the sample, though it does not change the inferences. We therefore discuss the influence of female employment in agriculture in the robustness tests section. Table 1 shows descriptive statistics of all variables included.

We estimate the model with Ordinary Least Squares (OLS) with robust standard errors that are clustered by region.

\section{Empirical results}

\subsection{Basic results}

Table 2 shows the regression results for education at the primary and secondary level. The control variables mostly display the expected signs and are statistically significant in most cases. The regional dummy variables are statistically significant at the $1 \%$ or

\footnotetext{
10 The British introduced Christianity to the African and Asian colonies. Most of the African countries are primarily Anglican or protestant and some countries follow their own variants of Christianity such as Independent Black Christian etc.

11 Brown (2000) illustrates the effect of colonialism on enrolment and Cooray (2009) the influence of colonialism on the adult literacy rate.
} 


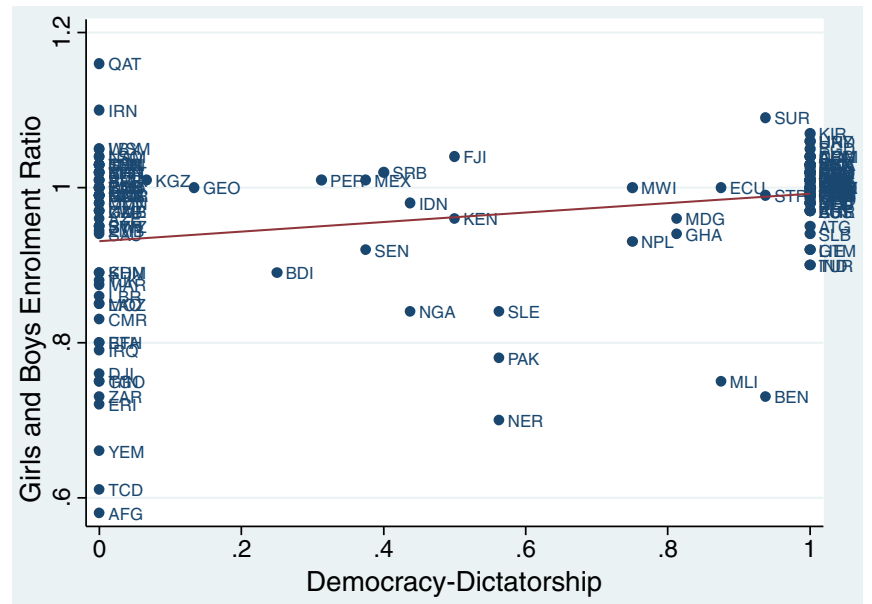

Fig. 2. Girls-and-boys enrolment ratio in primary and secondary education (2006) and democracy-dictatorship variable (average 1991-2005). Source: World Bank (2010) and Cheibub et al. (2010).

$5 \%$ level in columns (1) and (3) and have positive signs. The Middle East regional dummy variable is also statistically significant at the $5 \%$ level in columns (2) and (4). The regional dummy variables indicate that the girls-and-boys enrolment ratios have been higher in Middle East compared to Africa (reference category). The log real GDP per capita has the expected positive sign and is statistically significant at the $1 \%$ level in columns (2) and (4). It shows that the girls-and-boys enrolment ratios increased by about 4 percentage points when real GDP per capita increased by $1 \%$. Trade openness is not statistically significant. The government expenditure variable is statistically significant at the $1 \%$ level in column (2) with a negative sign but is not statistically significant in column (4). The numerical meaning of the coefficient is that girls-and-boys enrolment ratios decrease by about 0.15 percentage points when government expenditures (as a share of GDP) increases by one percentage point. The log population variable and the colony variable are not statistically significant.

The results in Table 2 show that democracy did not influence gender equality in education: the coefficient of the "Chief in Executive" variable has a positive sign in columns (1) and (2) but is not statistically significant. The coefficient of the DemocracyDictatorship variable has a negative sign but is not statistically significant in columns (3) and (4).

By contrast, the indigenous religion dummy variable is statistically significant at the $1 \%$ level in columns (1) to (4) with a negative sign. The Islam religion dummy variable also has a negative sign and is statistically significant at the $5 \%$ level in columns (1) and (3), at the $10 \%$ level in column (4), while it is not statistically significant at conventional levels in column (2). The indigenous religion and Islam religion dummy variables indicate that girls-and-boys enrolment ratios have been lower by about 18 and 6 percentage points in countries with Indigenous and Muslim religion compared to countries with Christian religion (reference category).

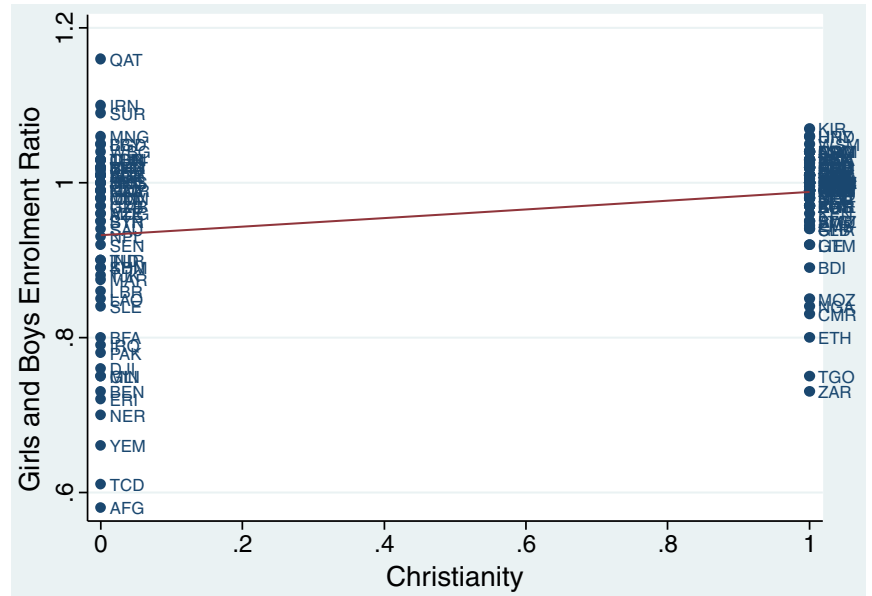

Fig. 3. Girls-and-boys enrolment ratio in primary and secondary education (2006) and Christianity. Source: World Bank (2010), The Encyclopaedia of World Geography (1994) and CIA World Factbook (2010). 


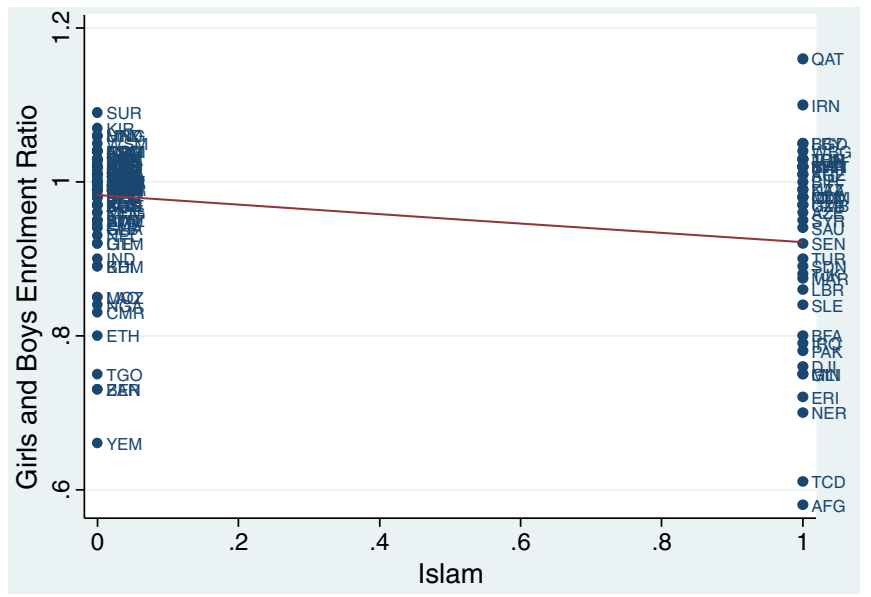

Fig. 4. Girls-and-boys enrolment ratio in primary and secondary education (2006) and Islam. Source: World Bank (2010), The Encyclopaedia of World Geography (1994) and CIA World Factbook (2010).

Table 3 illustrates the regression results for education at the tertiary level. Most of the control variables again display the expected signs. The log real GDP per capita variable is not statistically significant, however. Gender equality in tertiary education was significantly lower by about 60, 28 and 34 percentage points in countries with Buddhist, Muslim and Indigenous religion than

Table 1

Summary statistics.

\begin{tabular}{|c|c|c|c|c|c|c|}
\hline Variable & Obs. & Mean & St. dev & Min & Max & Source \\
\hline $\begin{array}{l}\text { Girls/boys in primary and secondary education (Ratio) } \\
2006\end{array}$ & 167 & 0.97 & 0.09 & 0.58 & 1.16 & World Bank (2010) \\
\hline $\begin{array}{l}\text { Girls/boys in tertiary education (Ratio) } \\
2006\end{array}$ & 132 & 1.17 & 0.74 & 0.06 & 6.26 & World Bank (2010) \\
\hline POLITY IV - constraints on Chief Executive & 154 & 4.60 & 2.04 & 1 & 7 & Marshall and Jaggers (2006) \\
\hline Democracy-Dictatorship & 185 & 0.55 & 0.47 & 0 & 1 & Cheibub et al. (2010) \\
\hline Africa & 210 & 0.24 & 0.43 & 0 & 1 & Own Calculation \\
\hline Asia & 210 & 0.12 & 0.33 & 0 & 1 & Own Calculation \\
\hline Middle East & 210 & 0.10 & 0.29 & 0 & 1 & Own Calculation \\
\hline Latin America & 210 & 0.15 & 0.36 & 0 & 1 & Own Calculation \\
\hline Eastern Europe & 210 & 0.14 & 0.35 & 0 & 1 & Own Calculation \\
\hline Western Europe & 210 & 0.14 & 0.35 & 0 & 1 & Own Calculation \\
\hline Northern America & 210 & 0.01 & 0.12 & 0 & 1 & Own Calculation \\
\hline Australia-Oceania & 210 & 0.08 & 0.27 & 0 & 1 & Own Calculation \\
\hline Christian & 210 & 0.61 & 0.49 & 0 & 1 & $\begin{array}{l}\text { The Encyclopaedia of World Geography (1994), } \\
\text { CIA World Factbook (2010) }\end{array}$ \\
\hline Buddhism & 210 & 0.07 & 0.25 & 0 & 1 & $\begin{array}{l}\text { The Encyclopaedia of World Geography (1994), } \\
\text { CIA World Factbook (2010) }\end{array}$ \\
\hline Islam & 210 & 0.25 & 0.43 & 0 & 1 & $\begin{array}{l}\text { The Encyclopaedia of World Geography (1994), } \\
\text { CIA World Factbook (2010) }\end{array}$ \\
\hline Hinduism & 210 & 0.02 & 0.15 & 0 & 1 & $\begin{array}{l}\text { The Encyclopaedia of World Geography (1994), } \\
\text { CIA World Factbook (2010) }\end{array}$ \\
\hline Indigenous religion & 210 & 0.01 & 0.12 & 0 & 1 & $\begin{array}{l}\text { The Encyclopaedia of World Geography (1994), } \\
\text { CIA World Factbook (2010) }\end{array}$ \\
\hline GDP per capita (constant prices) & 188 & 8615.46 & 9008.46 & 294.47 & 48970.31 & $\begin{array}{l}\text { Penn World Tables } 6.3 \\
\text { Summers and Heston (1991) }\end{array}$ \\
\hline $\begin{array}{l}\text { Trade openness } \\
\text { (as a share of GDP) }\end{array}$ & 188 & 0.87 & 0.46 & 0.02 & 3.60 & $\begin{array}{l}\text { Penn World Tables } 6.3 \\
\text { Summers and Heston (1991) }\end{array}$ \\
\hline Government expenditures & 188 & 0.21 & 0.11 & 0.04 & 0.67 & $\begin{array}{l}\text { Penn World Tables } 6.3 \\
\text { Summers and Heston (1991) }\end{array}$ \\
\hline Population & 210 & $2.81 \mathrm{E}+07$ & $1.13 E+08$ & 18206 & $1.24 \mathrm{E}+09$ & World Bank (2010) \\
\hline Colony & 189 & 0.41 & 0.49 & 0 & 1 & Own Calculation \\
\hline $\begin{array}{l}\text { Female employment in agriculture } \\
\text { (as a share of total employment) }\end{array}$ & 155 & 0.24 & 0.23 & 0.00 & 0.89 & World Bank (2010) \\
\hline Christian (Alesina et al.) & 210 & 0.46 & 0.37 & 0 & 1 & Alesina et al. (2003) \\
\hline Buddhism (Alesina et al.) & 210 & 0.04 & 0.18 & 0 & 0.96 & Alesina et al. (2003) \\
\hline Islam (Alesina et al.) & 210 & 0.23 & 0.36 & 0 & 1 & Alesina et al. (2003) \\
\hline Hinduism (Alesina et al.) & 210 & 0.02 & 0.10 & 0 & 0.93 & Alesina et al. (2003) \\
\hline Indigenous religion (Alesina et al.) & 210 & 0.04 & 0.11 & 0 & 0.64 & Alesina et al. (2003) \\
\hline
\end{tabular}


Table 2

Regression results. Dependent variable: girls-and-boys enrolment ratio in primary and secondary education. OLS with robust standard errors clustered by region.

\begin{tabular}{|c|c|c|c|c|}
\hline Variable & $(1)$ & $(2)$ & (3) & $(4)$ \\
\hline POLITY IV - constraints on Chief Executive & $\begin{array}{l}0.0102 \\
{[1.43]}\end{array}$ & $\begin{array}{l}0.0028 \\
{[0.43]}\end{array}$ & & \\
\hline Democracy-Dictatorship & & & $\begin{array}{l}-0.0024 \\
{[0.14]}\end{array}$ & $\begin{array}{l}-0.0158 \\
{[0.99]}\end{array}$ \\
\hline Buddhism & $\begin{array}{l}-0.0452 \\
{[0.42]}\end{array}$ & $\begin{array}{l}-0.0509 \\
{[0.58]}\end{array}$ & $\begin{array}{l}-0.0961 \\
{[0.92]}\end{array}$ & $\begin{array}{l}-0.0842 \\
{[1.10]}\end{array}$ \\
\hline Islam & $\begin{array}{l}-0.0615^{* *} \\
{[2.39]}\end{array}$ & $\begin{array}{l}-0.0558 \\
{[1.87]}\end{array}$ & $\begin{array}{l}-0.0803^{* *} \\
{[3.04]}\end{array}$ & $\begin{array}{l}-0.0650^{*} \\
{[2.21]}\end{array}$ \\
\hline Hinduism & $\begin{array}{l}-0.0248 \\
{[0.92]}\end{array}$ & $\begin{array}{l}-0.0243 \\
{[0.79]}\end{array}$ & $\begin{array}{l}0.0118 \\
{[0.20]}\end{array}$ & $\begin{array}{l}0.0069 \\
{[0.44]}\end{array}$ \\
\hline Indigenous religion & $\begin{array}{l}-0.1930^{* * *} \\
{[11.93]}\end{array}$ & $\begin{array}{l}-0.1852^{* * *} \\
{[9.55]}\end{array}$ & $\begin{array}{l}-0.1926^{* * *} \\
{[12.31]}\end{array}$ & $\begin{array}{l}-0.1725^{* * *} \\
{[10.61]}\end{array}$ \\
\hline Asia & $\begin{array}{l}0.0563 \\
{[1.03]}\end{array}$ & $\begin{array}{l}0.051 \\
{[0.93]}\end{array}$ & $\begin{array}{l}0.075 \\
{[1.76]}\end{array}$ & $\begin{array}{l}0.0508 \\
{[1.43]}\end{array}$ \\
\hline Middle East & $\begin{array}{l}0.1230^{* * *} \\
{[7.14]}\end{array}$ & $\begin{array}{l}0.0626^{* *} \\
{[2.80]}\end{array}$ & $\begin{array}{l}0.1209^{* * *} \\
{[6.33]}\end{array}$ & $\begin{array}{l}0.0634^{* *} \\
{[2.89]}\end{array}$ \\
\hline Latin America & $\begin{array}{l}0.0800^{* * *} \\
{[3.76]}\end{array}$ & $\begin{array}{l}0.04 \\
{[1.40]}\end{array}$ & $\begin{array}{l}0.0854^{* * * *} \\
{[5.81]}\end{array}$ & $\begin{array}{l}0.0402 \\
{[1.43]}\end{array}$ \\
\hline Eastern Europe & $\begin{array}{l}0.0814^{* * *} \\
{[5.96]}\end{array}$ & $\begin{array}{l}0.0451 \\
{[1.82]}\end{array}$ & $\begin{array}{l}0.0905^{* * *} \\
{[11.11]}\end{array}$ & $\begin{array}{l}0.0513^{*} \\
{[2.29]}\end{array}$ \\
\hline Western Europe & $\begin{array}{l}0.0561^{*} \\
{[1.93]}\end{array}$ & $\begin{array}{l}-0.0327 \\
{[0.77]}\end{array}$ & $\begin{array}{l}0.0736^{* * *} \\
{[4.42]}\end{array}$ & $\begin{array}{l}-0.0207 \\
{[0.51]}\end{array}$ \\
\hline North America & $\begin{array}{l}0.0516 \\
{[1.75]}\end{array}$ & $\begin{array}{l}-0.0327 \\
{[0.72]}\end{array}$ & $\begin{array}{l}0.0725^{* * *} \\
{[4.36]}\end{array}$ & $\begin{array}{l}-0.0211 \\
{[0.48]}\end{array}$ \\
\hline Australia-Oceania & $\begin{array}{l}0.0542^{*} \\
{[1.95]}\end{array}$ & $\begin{array}{l}0.0087 \\
{[0.27]}\end{array}$ & $\begin{array}{l}0.0874^{* * *} \\
{[6.86]}\end{array}$ & $\begin{array}{l}0.0401 \\
{[1.83]}\end{array}$ \\
\hline Log real GDP per capita & & $\begin{array}{l}0.0386^{* * * *} \\
{[3.80]}\end{array}$ & & $\begin{array}{l}0.0402^{* * * *} \\
{[3.50]}\end{array}$ \\
\hline Trade openness & & $\begin{array}{l}0.0043 \\
{[0.28]}\end{array}$ & & $\begin{array}{l}0.0008 \\
{[0.05]}\end{array}$ \\
\hline Government expenditures & & $\begin{array}{l}-0.1524^{* * *} \\
{[4.03]}\end{array}$ & & $\begin{array}{l}-0.1058 \\
{[1.81]}\end{array}$ \\
\hline Log population & & $\begin{array}{l}-0.0075 \\
{[1.37]}\end{array}$ & & $\begin{array}{l}-0.0063 \\
{[1.17]}\end{array}$ \\
\hline Colony & & $\begin{array}{l}-0.0035 \\
{[0.24]}\end{array}$ & & $\begin{array}{l}-0.0031 \\
{[0.17]}\end{array}$ \\
\hline Constant & $\begin{array}{l}0.8721^{* * *} \\
{[38.15]}\end{array}$ & $\begin{array}{l}0.7665^{* * *} \\
{[5.40]}\end{array}$ & $\begin{array}{l}0.9249^{* * *} \\
{[137.79]}\end{array}$ & $\begin{array}{l}0.7479^{* * *} \\
{[4.56]}\end{array}$ \\
\hline Obs. & 135 & 132 & 157 & 151 \\
\hline$R$-squared & 0.37 & 0.51 & 0.34 & 0.51 \\
\hline
\end{tabular}

Absolute value of t statistics in brackets; * significant at $10 \% ;{ }^{* *}$ significant at $5 \% ;{ }^{* * *}$ significant at $1 \%$.

in countries with predominant Christian religion. The democracy variables are not statistically significant, suggesting that political institutions do not influence gender equality in education.

\subsection{Robustness tests}

We checked the robustness of the results in several ways. Gender equality has been very pronounced in (1) socialist countries and (2) high-income countries. We therefore excluded all Eastern European countries and high-income countries (threshold 3855 USD per capita following World Bank definitions), because the socialist and established democratic past might bias our estimates.

The results reported in Table 4 indicate that excluding the former socialist European and high income countries changes our base-line inferences in favour of a positive influence of democracy on gender equality in education. The "Chief in Executive variable" is statistically significant at the $5 \%$ level in columns (1) and (2). The Democracy-Dictatorship variable in columns (3) and (4) is not statistically significant at conventional levels. The positive influence of the "Chief in Executive" variable is not robust, however, when we perform further robustness tests for the smaller sample excluding Eastern European and high income countries (e.g., slightly varying the high/low income threshold).

Table 5 shows that democracy does not have an influence on the girls-and-boys enrolment ratios in tertiary education when Eastern European and high income countries are excluded. By contrast, the results in Table 4 show that gender equality in education was significantly lower in countries with Muslim majorities and countries with Indigenous Religion: the Islam and Indigenous Religion dummy variables have negative signs and are statistically significant at the $1 \%$ level. The religion variables have a somewhat weaker effect on gender equality in education at the tertiary level when Eastern European and high income countries are excluded (Table 5) but inferences regarding the influence of religion on gender equality in education do not change. 
Table 3

Regression results. Dependent variable: girls-and-boys enrolment ratio in tertiary education. OLS with robust standard errors clustered by region.

\begin{tabular}{|c|c|c|c|c|}
\hline Variable & $(1)$ & (2) & (3) & (4) \\
\hline POLITY IV - constraints on Chief Executive & $\begin{array}{l}-0.0272 \\
{[0.39]}\end{array}$ & $\begin{array}{l}-0.0757 \\
{[1.09]}\end{array}$ & & \\
\hline Democracy-Dictatorship & & & $\begin{array}{l}-0.168 \\
{[0.97]}\end{array}$ & $\begin{array}{l}-0.2407 \\
{[1.71]}\end{array}$ \\
\hline Buddhism & $\begin{array}{l}-0.3768 \\
{[0.76]}\end{array}$ & $\begin{array}{l}-0.5732^{* *} \\
{[2.91]}\end{array}$ & $\begin{array}{l}-0.7161^{* *} \\
{[2.40]}\end{array}$ & $\begin{array}{l}-0.6360^{* * *} \\
{[3.87]}\end{array}$ \\
\hline Islam & $\begin{array}{l}-0.2437^{*} \\
{[2.33]}\end{array}$ & $\begin{array}{l}-0.3071^{\text {** }} \\
{[3.46]}\end{array}$ & $\begin{array}{l}-0.2894^{* * *} \\
{[4.49]}\end{array}$ & $\begin{array}{l}-0.2795^{* *} \\
{[3.21]}\end{array}$ \\
\hline Hinduism & $\begin{array}{l}0.3781 \\
{[1.09]}\end{array}$ & $\begin{array}{l}0.2829 \\
{[0.68]}\end{array}$ & $\begin{array}{l}0.2714 \\
{[0.71]}\end{array}$ & $\begin{array}{l}0.2776 \\
{[0.65]}\end{array}$ \\
\hline Indigenous religion & $\begin{array}{l}-0.3763^{* * *} \\
{[12.47]}\end{array}$ & $\begin{array}{l}-0.3686^{* *} \\
{[3.00]}\end{array}$ & $\begin{array}{l}-0.3583^{* * *} \\
{[4.87]}\end{array}$ & $\begin{array}{l}-0.2874^{*} \\
{[2.17]}\end{array}$ \\
\hline Asia & $\begin{array}{l}0.4985 \\
{[1.70]}\end{array}$ & $\begin{array}{l}0.6264^{* *} \\
{[2.58]}\end{array}$ & $\begin{array}{l}0.7011^{* * *} \\
{[4.88]}\end{array}$ & $\begin{array}{l}0.4951^{* *} \\
{[2.78]}\end{array}$ \\
\hline Middle East & $\begin{array}{l}1.1443^{* * *} \\
{[14.54]}\end{array}$ & $\begin{array}{l}0.7307^{* *} \\
{[2.55]}\end{array}$ & $\begin{array}{l}1.1410^{* * *} \\
{[20.33]}\end{array}$ & $\begin{array}{l}0.7170^{* *} \\
{[2.64]}\end{array}$ \\
\hline Latin America & $\begin{array}{l}0.6465^{* * *} \\
{[4.78]}\end{array}$ & $\begin{array}{l}0.4058 \\
{[1.75]}\end{array}$ & $\begin{array}{l}0.6509^{* * *} \\
{[6.10]}\end{array}$ & $\begin{array}{l}0.4505^{* * *} \\
{[4.07]}\end{array}$ \\
\hline Eastern Europe & $\begin{array}{l}0.7134^{* * *} \\
{[6.46]}\end{array}$ & $\begin{array}{l}0.4943 \\
{[1.57]}\end{array}$ & $\begin{array}{l}0.7083^{* * *} \\
{[10.27]}\end{array}$ & $\begin{array}{l}0.5595^{* *} \\
{[3.13]}\end{array}$ \\
\hline Western Europe & $\begin{array}{l}0.6846^{* *} \\
{[3.05]}\end{array}$ & $\begin{array}{l}0.0702 \\
{[0.27]}\end{array}$ & $\begin{array}{l}0.6733^{* * *} \\
{[4.93]}\end{array}$ & $\begin{array}{l}0.0594 \\
{[0.35]}\end{array}$ \\
\hline North America & $\begin{array}{l}0.8370^{* * *} \\
{[3.66]}\end{array}$ & $\begin{array}{l}0.4355 \\
{[1.57]}\end{array}$ & $\begin{array}{l}0.8347^{* * *} \\
{[6.11]}\end{array}$ & $\begin{array}{l}0.3128 \\
{[1.16]}\end{array}$ \\
\hline Australia-Oceania & $\begin{array}{l}0.7446^{* * *} \\
{[3.62]}\end{array}$ & $\begin{array}{l}0.1276 \\
{[0.67]}\end{array}$ & $\begin{array}{l}0.7234^{* * *} \\
{[6.68]}\end{array}$ & $\begin{array}{l}0.1046 \\
{[0.60]}\end{array}$ \\
\hline Log real GDP per capita & & $\begin{array}{l}0.3384 \\
{[1.67]}\end{array}$ & & $\begin{array}{l}0.3495 \\
{[1.86]}\end{array}$ \\
\hline Trade openness & & $\begin{array}{l}-0.1171 \\
{[0.42]}\end{array}$ & & $\begin{array}{l}-0.2214 \\
{[0.99]}\end{array}$ \\
\hline Government expenditures & & $\begin{array}{l}-0.1862 \\
{[0.64]}\end{array}$ & & $\begin{array}{l}-0.0573 \\
{[0.19]}\end{array}$ \\
\hline Log population & & $\begin{array}{l}-0.1241 \\
{[1.72]}\end{array}$ & & $\begin{array}{l}-0.1029^{*} \\
{[2.08]}\end{array}$ \\
\hline Colony & & $\begin{array}{l}0.1498 \\
{[0.41]}\end{array}$ & & $\begin{array}{l}0.2371 \\
{[0.76]}\end{array}$ \\
\hline Constant & $\begin{array}{l}0.7631^{* *} \\
{[2.85]}\end{array}$ & $\begin{array}{l}0.4529 \\
{[0.65]}\end{array}$ & $\begin{array}{l}0.7433^{* * *} \\
{[15.86]}\end{array}$ & $\begin{array}{l}-0.2275 \\
{[0.19]}\end{array}$ \\
\hline Obs. & 115 & 112 & 123 & 119 \\
\hline$R$-squared & 0.29 & 0.52 & 0.29 & 0.54 \\
\hline
\end{tabular}

Absolute value of $t$ statistics in brackets; * significant at $10 \%$; ${ }^{* *}$ significant at $5 \%$; ${ }^{* * *}$ significant at $1 \%$.

The results presented in Tables 2-5 could be subject to omitted variable bias. We have therefore included female employment in agriculture (as a share of total employment) because employment in agriculture has been traditionally associated with greater gender and income inequality in favour of males. Female employment in agriculture has negatively influenced gender equality in education at the primary and secondary level. Female employment in agriculture has the expected negative sign and is statistically significant at the $1 \%$ level. Including female employment in agriculture significantly reduces the sample and even turns the democracy variable to a negative influence on gender equality in education (results not shown). This robustness test confirms that the influence of democracy on gender equality in education strongly depends on the countries included in the sample. Inferences regarding religion do not change.

In the base-line model, we have employed cross-sectional data on girls-and-boys enrolment ratios for the year 2006 and regressed it on averages of the democracy variables over the 1991-2005 period. We now replace the cross-sectional data on girlsand-boys enrolment ratios for the year 2006 by the data for the year 2001 and regress it on averages of the democracy variables over the 1991-2000 period. ${ }^{12}$ The influence of democracy and religion on gender equality in education could have somewhat changed from 2001 to 2006 because gender equality increased in some countries in that period. The results are very similar to the results presented in Tables 2-5 and inferences regarding the influence of democracy and religion on gender equality in education do not change.

The girls-and-boys enrolment ratio at the tertiary level of education may well depend on the girls-and-boys enrolment ratio at the primary and secondary level of education. We have therefore included the girls-and-boys enrolment ratio at the primary and secondary level of education in 2001 as an explanatory variable in our model with the girls-and-boys enrolment ratio at the

\footnotetext{
12 We choose the years 2001 and 2006 because most data are available for these two years. For some countries, data are not available for 2001 but for 2000 or 2002, we then use the data for 2000 or 2002 to include as much countries as possible.
} 
Table 4

Regression results. Dependent variable: girls-and-boys enrolment ratio in primary and secondary education. OLS with robust standard errors clustered by region. Eastern European and high income countries excluded.

\begin{tabular}{|c|c|c|c|c|}
\hline Variable & $(1)$ & (2) & (3) & $(4)$ \\
\hline POLITY IV - constraints on Chief Executive & $\begin{array}{l}0.0284^{* *} \\
{[2.83]}\end{array}$ & $\begin{array}{l}0.0245^{* *} \\
{[4.29]}\end{array}$ & & \\
\hline Democracy-Dictatorship & & & $\begin{array}{l}0.0352 \\
{[0.92]}\end{array}$ & $\begin{array}{l}0.0357 \\
{[1.16]}\end{array}$ \\
\hline Buddhism & $\begin{array}{l}-0.0466 \\
{[0.40]}\end{array}$ & $\begin{array}{l}-0.0565 \\
{[0.53]}\end{array}$ & $\begin{array}{l}-0.104 \\
{[0.85]}\end{array}$ & $\begin{array}{l}-0.0795 \\
{[0.70]}\end{array}$ \\
\hline Islam & $\begin{array}{l}-0.0704^{* *} \\
{[3.71]}\end{array}$ & $\begin{array}{l}-0.0848^{* * *} \\
{[4.99]}\end{array}$ & $\begin{array}{l}-0.0907^{* * *} \\
{[10.71]}\end{array}$ & $\begin{array}{l}-0.0940^{* * *} \\
{[6.45]}\end{array}$ \\
\hline Hinduism & $\begin{array}{l}-0.0751 \\
{[1.57]}\end{array}$ & $\begin{array}{l}-0.0628 \\
{[2.02]}\end{array}$ & $\begin{array}{l}-0.0696 \\
{[1.82]}\end{array}$ & $\begin{array}{l}-0.0465 \\
{[1.57]}\end{array}$ \\
\hline Indigenous religion & $\begin{array}{l}-0.2148^{* * *} \\
{[15.93]}\end{array}$ & $\begin{array}{l}-0.2357^{* * *} \\
{[28.91]}\end{array}$ & $\begin{array}{l}-0.2020^{* * *} \\
{[7.52]}\end{array}$ & $\begin{array}{l}-0.2200^{* * *} \\
{[16.80]}\end{array}$ \\
\hline Asia & $\begin{array}{l}0.0537 \\
{[0.99]}\end{array}$ & $\begin{array}{l}0.0106 \\
{[0.15]}\end{array}$ & $\begin{array}{l}0.0828 \\
{[1.70]}\end{array}$ & $\begin{array}{l}0.0266 \\
{[0.38]}\end{array}$ \\
\hline Middle East & $\begin{array}{l}0.0837^{* * *} \\
{[5.57]}\end{array}$ & $\begin{array}{l}0.0802^{* *} \\
{[3.34]}\end{array}$ & $\begin{array}{l}0.0739^{* * *} \\
{[5.26]}\end{array}$ & $\begin{array}{l}0.0774^{* *} \\
{[3.03]}\end{array}$ \\
\hline Latin America & $\begin{array}{l}0.0637^{* *} \\
{[3.65]}\end{array}$ & $\begin{array}{l}-0.0722 \\
{[2.10]}\end{array}$ & $\begin{array}{l}0.1045^{* * *} \\
{[4.92]}\end{array}$ & $\begin{array}{l}-0.0031 \\
{[0.08]}\end{array}$ \\
\hline Australia-Oceania & $\begin{array}{l}-0.0617 \\
{[1.89]}\end{array}$ & $\begin{array}{l}-0.0816^{* *} \\
{[3.45]}\end{array}$ & $\begin{array}{l}0.0757^{*} \\
{[2.59]}\end{array}$ & $\begin{array}{l}0.0524^{* *} \\
{[3.21]}\end{array}$ \\
\hline Log real GDP per capita & & $\begin{array}{l}0.0884^{*} \\
{[2.23]}\end{array}$ & & $\begin{array}{l}0.0851 \\
{[1.86]}\end{array}$ \\
\hline Trade openness & & $\begin{array}{l}0.0262 \\
{[0.58]}\end{array}$ & & $\begin{array}{l}0.0421 \\
{[1.27]}\end{array}$ \\
\hline Government expenditures & & $\begin{array}{l}-0.2101^{\text {**** }} \\
{[4.79]}\end{array}$ & & $\begin{array}{l}-0.2096^{* * *} \\
{[4.61]}\end{array}$ \\
\hline Log population & & $\begin{array}{l}-0.0142 \\
{[1.96]}\end{array}$ & & $\begin{array}{l}-0.0079 \\
{[1.27]}\end{array}$ \\
\hline Colony & & $\begin{array}{l}-0.0493^{* *} \\
{[3.78]}\end{array}$ & & $\begin{array}{l}-0.0166 \\
{[1.33]}\end{array}$ \\
\hline Constant & $\begin{array}{l}0.8026^{* * *} \\
{[20.70]}\end{array}$ & $\begin{array}{l}0.5013 \\
{[1.67]}\end{array}$ & $\begin{array}{l}0.8990^{* * * *} \\
{[90.20]}\end{array}$ & $\begin{array}{l}0.4591 \\
{[1.35]}\end{array}$ \\
\hline Obs. & 52 & 51 & 55 & 53 \\
\hline$R$-squared & 0.32 & 0.53 & 0.29 & 0.50 \\
\hline
\end{tabular}

Absolute value of $t$ statistics in brackets; * significant at $10 \% ;{ }^{* *}$ significant at $5 \%$; ${ }^{* * *}$ significant at $1 \%$.

tertiary level of education in 2006 as dependent variable. The girls-and-boys enrolment ratio at the primary and secondary level of education in 2001 has a positive sign and is statistically significant at the $10 \%$ level in the base-line model and at the $5 \%$ level in the subsample when Eastern European and high income countries are excluded. Including the girls-and-boys enrolment ratio at the primary and secondary of education in 2001 does not change the inferences regarding the democracy and religion variables.

We have focused on discrimination against girls. Girls-and-boys enrolment ratios that are significantly higher than 1 can also be interpreted as discrimination, against boys, however. We have therefore excluded all countries that have enrolment ratios in primary and secondary education higher than 1.05 and 1.1 and enrolment ratios in tertiary education higher than $1.05,1.1,1.5,2.0$ (the variance of enrolment ratios in tertiary education is higher than in primary and secondary education). Enrolment ratios are especially high in some countries. The reason may well be that male dominant elites do not care about education because men will rule anyhow and consider education as a waste of time. Excluding the countries with high enrolment ratios does not, however, make the democracy variables statistically significant.

Democracies can be coded more expansively. Cheibub et al. (2010) have conservatively coded countries as democracy only if there has been alternation in power. Some countries appear, however, to have "contested" elections for the executive and legislature, but there has never been an alternation of the government in power. The data by Cheibub et al. (2010) also allow consideration of these cases as democracies in addition to their conservative coding. We have included the more expansive democracy coding. Results suggest that the more expansive democracy variables do not have an influence on gender equality in education (results not shown).

We have replaced the religion dummy variables using information from The Encyclopedia of World Geography (1994) and the CIA World Factbook (2010) by the data on religious fractionalization by Alesina et al. (2003). This database reports for each country in the year 1980 the percentage of the population belonging to the three most widespread religions in the world. We again distinguish Christianity, Buddhism, Islam, Hinduism and Indigenous Religion. Inferences are very similar to the results with the dummy variables on religion. In fact, the negative influence of Islam on gender equality in education is more severe with the data by Alesina et al. (2003). 
Table 5

Regression results. Dependent variable: girls-and-boys enrolment ratio in tertiary education. OLS with robust standard errors clustered by region. Eastern European and high income countries excluded.

\begin{tabular}{|c|c|c|c|c|}
\hline Variable & (1) & (2) & (3) & $(4)$ \\
\hline POLITY IV - constraints on Chief Executive & $\begin{array}{l}0.0624 \\
{[1.41]}\end{array}$ & $\begin{array}{l}0.0259 \\
{[0.81]}\end{array}$ & & \\
\hline Democracy-Dictatorship & & & $\begin{array}{l}-0.2453 \\
{[0.81]}\end{array}$ & $\begin{array}{l}-0.1496 \\
{[0.84]}\end{array}$ \\
\hline Buddhism & $\begin{array}{l}-0.0993 \\
{[0.41]}\end{array}$ & $\begin{array}{l}-0.2956 \\
{[1.79]}\end{array}$ & $\begin{array}{l}-0.5366^{*} \\
{[2.48]}\end{array}$ & $\begin{array}{l}-0.4676^{* *} \\
{[3.86]}\end{array}$ \\
\hline Islam & $\begin{array}{l}-0.136 \\
{[1.42]}\end{array}$ & $\begin{array}{l}-0.1637 \\
{[1.83]}\end{array}$ & $\begin{array}{l}-0.2083^{* *} \\
{[4.21]}\end{array}$ & $\begin{array}{l}-0.1980^{* *} \\
{[4.00]}\end{array}$ \\
\hline Hinduism & $\begin{array}{l}0.2513 \\
{[0.30]}\end{array}$ & $\begin{array}{l}0.2223 \\
{[0.81]}\end{array}$ & $\begin{array}{l}0.2301 \\
{[0.38]}\end{array}$ & $\begin{array}{l}0.1613 \\
{[0.63]}\end{array}$ \\
\hline Indigenous religion & $\begin{array}{l}-0.3302^{* * *} \\
{[6.82]}\end{array}$ & $\begin{array}{l}-0.2752^{* *} \\
{[3.89]}\end{array}$ & $\begin{array}{l}-0.2338 \\
{[2.05]}\end{array}$ & $\begin{array}{l}-0.1892 \\
{[1.35]}\end{array}$ \\
\hline Asia & $\begin{array}{l}0.2821 \\
{[2.35]}\end{array}$ & $\begin{array}{l}0.3036 \\
{[2.05]}\end{array}$ & $\begin{array}{l}0.5004^{*} \\
{[2.88]}\end{array}$ & $\begin{array}{l}0.3822^{* *} \\
{[3.70]}\end{array}$ \\
\hline Middle East & $\begin{array}{l}0.4662^{* *} \\
{[4.46]}\end{array}$ & $\begin{array}{l}0.4839^{* * * *} \\
{[6.23]}\end{array}$ & $\begin{array}{l}0.4658^{* * *} \\
{[10.29]}\end{array}$ & $\begin{array}{l}0.4762^{* *} \\
{[4.06]}\end{array}$ \\
\hline Latin America & $\begin{array}{l}0.6534 \\
{[2.10]}\end{array}$ & $\begin{array}{l}0.0867 \\
{[0.40]}\end{array}$ & $\begin{array}{l}0.8505^{*} \\
{[2.95]}\end{array}$ & $\begin{array}{l}0.4271^{*} \\
{[2.81]}\end{array}$ \\
\hline Australia-Oceania & - & $\begin{array}{l}- \\
-\end{array}$ & - & $\begin{array}{l}- \\
-\end{array}$ \\
\hline Log real GDP per capita & & $\begin{array}{l}0.0435 \\
{[0.56]}\end{array}$ & & $\begin{array}{l}0.051 \\
{[0.63]}\end{array}$ \\
\hline Trade openness & & $\begin{array}{l}0.6397^{*} \\
{[2.91]}\end{array}$ & & $\begin{array}{l}0.6106^{* *} \\
{[4.07]}\end{array}$ \\
\hline Government expenditures & & $\begin{array}{l}-0.666 \\
{[1.59]}\end{array}$ & & $\begin{array}{l}-0.6105 \\
{[1.78]}\end{array}$ \\
\hline Log population & & $\begin{array}{l}-0.0125 \\
{[0.66]}\end{array}$ & & $\begin{array}{l}0.0158 \\
{[0.40]}\end{array}$ \\
\hline Colony & & $\begin{array}{l}-0.2437 \\
{[1.51]}\end{array}$ & & $\begin{array}{l}-0.0703 \\
{[1.85]}\end{array}$ \\
\hline Constant & $\begin{array}{l}0.3647^{*} \\
{[2.59]}\end{array}$ & $\begin{array}{l}0.3989 \\
{[0.82]}\end{array}$ & $\begin{array}{l}0.6671^{* * *} \\
{[8.54]}\end{array}$ & $\begin{array}{l}-0.136 \\
{[0.13]}\end{array}$ \\
\hline Obs. & 39 & 38 & 39 & 38 \\
\hline$R$-squared & 0.51 & 0.79 & 0.58 & 0.8 \\
\hline
\end{tabular}

Absolute value of $t$ statistics in brackets; * significant at $10 \%$; ${ }^{* *}$ significant at $5 \%$; ${ }^{* * *}$ significant at $1 \%$.

The reported effects could also be driven or mitigated by idiosyncratic circumstances in individual countries. For this reason, we checked whether the results are sensitive to the inclusion/exclusion of particular countries. The results (not reported here) indicate that this is not the case.

\section{Conclusion}

There have been numerous studies of government decisions in countries with limited democratic institutions. Such governments have incentives to resist economic development in various ways (Hillman, 2007). Most prominently, aid given to such government does not improve the well-being of the general population (Doucouliagos and Paldam, 2008). We have investigated whether political institutions affect gender equality in education, with the counter explanation being culture and religion. The results suggest no robust effect of democratic political institutions on discrimination against girls in education. We find no evidence of gender discrimination in forestalling education in autocracies. Likewise, there is no gender discrimination in promoting education in democracies. The influence is through culture and religion rather than political institutions.

Given the benefits of educating girls, and the significant disadvantages of limited or absent democracy in low-income countries, why is it that democracy has not advanced gender equality in education? Several developing countries have become democracies since the 1990s. Democracy has not always, however, delivered the beneficial results it promised.

Success of democratization and its influence on gender equality clearly differs across regions. In Eastern Europe, gender equality in education has been pronounced for a long time. Communist countries had high rates of full-time maternal employment, extensive public child care systems and gender equality in education. After communism collapsed, however, women could be disadvantaged. ${ }^{13}$ Women did not play a central role in the democratization process in Eastern Europe; no widespread feminist organizations emerged. By contrast, women's movements played an important role in democratization and increasing gender equality in Latin America since the late 1970s (e.g., Waylen, 1994: 335 ff.). Countries such as Argentina became

13 Waylen (1994: 353) observed that the "wider changes associated with democratization, such as market liberalization and the assertion of "traditional" values of God, family, and nation often have a negative impact on women, particularly in terms of their strategic gender interests". 
democracies and women's rights and gender equality improved. Since the 1990s, however, distrust of government, of politicians and of political parties appears to have increased in many Latin American countries, and democratization has been less successful (Antonopoulos and Cos-Montiel, 2007: 9 f.).

In OECD countries, which have been democracies for several years, gender equality in education is indicated in girls-and-boys ratios of about nearly 1 . By contrast, in developing countries - independently of whether they have become democracies over the 1991-2005 period - girls-and-boys ratios have taken on extreme values. In countries such as Afghanistan, Chad and Yemen, discrimination against girls in education is dramatic. All three countries are autocracies and thus confirm our original hypothesis that the more limited is democracy, the greater is the bias against educating girls, and therefore the greater is gender inequality in education. Other autocratic regimes such as Qatar have, however, much more pronounced gender equality in education.

Tsai (2006) has investigated the influence of democracy on human development in developing countries in the 1980s and 1990s. Her results show that dictatorships outperformed democracies in speeding up school enrolment at the primary and secondary level. Tsai (2006) does not distinguish between female and male enrolment, however. In a similar vein, countries such as Benin and Turkey have become more democratic in recent years, but gender equality in education is still quite low.

Modernization may lead to both democratization and cultural change favoring gender equality. Inglehart et al. (2002), for example, investigate the relationship between gender equality and democratization by focusing on the role of women in parliament and politics. They conclude that "support for gender equality is not just a consequence of democratization. It is part of a broad cultural change that is transforming industrialized societies and bringing growing mass demands for increasingly democratic institutions" (p. 343).

An important aspect of cultural change is how religion affects institutions and behaviour. Religion influences the level of democracy. Muslim countries stand out in being more authoritarian and less democratic (Borooah and Paldam, 2007). Muslim countries also have less gender equality (Norton and Tomal, 2009): our empirical results indicate that the gender inequality is not attributable to the absence of democracy but to culture and religion.

\section{Acknowledgements}

We thank three anonymous referees, Christian Bjørnskov, Arye Hillman, Winfried Pohlmeier, Heinrich Ursprung and the participants of the Far East and South Asia Meeting of the Econometric Society, Tokyo, 2009, the Australasian Development Economics Workshop, Sydney, 2010, and the International Society for New Institutional Economics, Stirling, 2010, for the useful hints and suggestions.

\section{References}

Acemoglu, D., Johnson, S., Robinson, J., Yared, P., 2005. From education to democracy. American Economic Association Papers and Proceedings 95, 44-49.

Adams, M., 2006. Colonial policies and women's participation in public life: the case of British Southern Cameroons. African Studies Quarterly 8, 1-22.

Alesina, A., Devleeschauwer, A., Easterley, W., Kurlat, S., Wacziarg, R., 2003. Fractionalization. Journal of Economic Growth 8, $155-194$.

Antonopoulos, R., Cos-Montiel, F., 2007. State, difference, and diversity: toward a path of expanded democracy and gender equality. Working Paper No 493. The Levy Economics Institute, London.

Baliamoune-Lutz, M., McGillivray, M., 2007. Gender inequality and growth: Evidence from Sub-Saharan and Arab countries. http://www.uneca.org/aec/documents/Mina\% 20Baliamoune-Lutz.pdf2007(downloaded February 2009).

Barrett, D., Kurian, Johnson, T.M., 2001. World Christian Encyclopedia, 2nd Ed. Oxford University Press, Oxford.

Barro, R., 1999. Determinants of democracy. Journal of Political Economy 107, 158-183.

Barro, R., Lee, J.-W., 1993. International comparisons of educational attainment. Journal of Monetary Economics 32, 363-394

Beaman, L., Chattopadhhyay, R., Duflo, E., Pande, R., Topalova, P., 2009. Powerful women: does exposure reduce bias? Quarterly Journal of Economics 124, 1497-1540.

Becker, S., Woessmann, L., 2008. Luther and the girls: religious denomination and the female education gap in nineteenth-century Prussia. Scandinavia Journal of Economics 110, 777-805

Becker, S., Woessmann, L., 2009. Was Weber wrong? A human capital theory of Protestant economic history. Quarterly Journal of Economics 124, 531-596.

Becker, S., Woessmann, L., 2010. The effect of Protestantism on education before industrialization: evidence from 1816 Prussia. Economics Letters 107, $224-228$.

Beer, C., 2009. Democracy and gender equality. Studies in International Comparative Development 44, $212-227$.

Borooah, V.K., Paldam, M., 2007. Why is the world short of democracy? A cross-country analysis of barriers to representative government. European Journal of Political Economy 23, 582-604.

Bourguignon, F., Verdier, T., 2000. Ruling elite, democracy, inequality and growth. Journal of Development Economics 62, $285-313$.

Brown, D., 2000. Democracy, colonization, and human capital in Sub-Saharan Africa. Studies in Comparative International Development 35, 20-40.

Brown, D., 2004. Democracy and gender inequality in education: a cross national examination. British Journal of Political Science 34, 137-152.

Cagaty, N., Ozler, S., 1995. Feminization of the labour force: the effects of long term development and structural adjustment. World Development 23, $1883-1894$.

Castelló-Climent, A., 2008. On the distribution of education and democracy. Journal of Development Economics 87, 179-190.

Cheibub, J., Gandhi, J., Vreeland, J., 2010. Democracy and dictatorship revisited. Public Choice 143, 67-101.

CIA World Factbook, 2010. https://www.cia.gov/library/publications/the-world-factbook/2010downloaded April 2010.

Cooray, A., 2009. Does colonialism exert a long term economic impact on adult literacy? Working Paper No. 176. Queen Elizabeth House. University of Oxford, Oxford, U.K.

Di Gioacchino, D., Sabani, L., 2009. Education policy and inequality: a political economy analysis. European Journal of Political Economy 25 , 463-478.

Di Tommaso, M.L., Shima, I., Strøm, S., Bettio, F., 2009. As bad as it gets: well-being deprivation of sexually exploited women. European Journal of Political Economy 25, 143-162.

Doepke, M., Tertilt, M., 2009. Women's liberation: what's in it for men? Quarterly Journal of Economics 124, 1541-1591.

Dollar, D., Gatti, R., 1999. Gender inequality, income and growth: are good times good for women? Policy Research Report on Gender and Development Working Paper Series No. 1, World Bank, Washington DC.

Doucouliagos, H., Paldam, M., 2008. Aid effectiveness on growth: a meta study. European Journal of Political Economy 24, 1-24.

Fernandez, R., Fogli, A., Olivetti, C., 2004. Mothers and sons: preference formation and female labor force dynamics. Quarterly Journal of Economics 119, 1249-1299.

Fontana, M., Wood, A., 2000. Modelling the effects of trade on women, at work and at home. World Development 28, 1173-1190. 
Glaeser, E., La Porta, R., Lopez-de-Silanes, F., Shleifer, A., 2004. Do institutions cause growth? Journal of Economic Growth 9, $271-303$.

Gundlach, E., Paldam, M., 2009. A farewell to critical junctures: sorting out long-run causality of income and democracy. European Journal of Political Economy 25, $340-354$.

Hillman, A.L., 2004. Nietzschean development failures. Public Choice 119, 263-280.

Hillman, A.L., 2007. Democracy and low-income countries. In: Casas Pardo, J., Schwartz, P. (Eds.), Public Choice and Challenges of Democracy. Edward Elgar, Cheltenham, U.K, pp. 277-294.

Hillman, A.L., 2009. Public finance and public policy: responsibilities and limitations of government, 2nd Ed. Cambridge University Press, New York.

Hillman, A.L., Jenkner, E., 2004. User payments for basic education in low-income countries. In: Gupta, S., Clements, B., Inchauste, G. (Eds.), Helping countries Develop: The Role of Fiscal Policy. International Monetary Fund, Washington DC, pp. 233-264.

Inglehart, R., Baker, W., 2000. Modernization, cultural change and the persistence of traditional values. American Sociological Review 65, 19-51.

Inglehart, R., Norris, P., Welzel, C., 2002. Gender equality and democracy. Comparative Sociology 1, 321-345.

Klasen, S., 2002. Low schooling for girls, slower growth for all? Cross country evidence on the effect of gender inequality in education on economic development. World Bank Economic Review 16, 345-373.

Klasen, S., Wink, C., 2003. Missing women: revisiting the debate. Feminist Economics 9, 263-299.

Knowles, S., Lorgelly, P., Ownen, P., 2002. Are educational gender gaps a brake on economic development? Some cross country empirical evidence. Oxford Economic Papers 54, 118-149.

Larson, A., 2009. Toward an Afghan democracy? Exploring perceptions of democratisation in Afghanistan. Working Paper, Afghanistan Research and Evaluation Unit Kabul.

Marshall, M., Jaggers, K., 2006. Polity IV Country Reports. http://www.systemicpeace.org/polity/polity06.htm\#nam2006downloaded January 2010.

Munck, G., Verkuilen, J., 2002. Conceptualizing and measuring democracy: evaluating alternative indices. Comparative Political Studies 55, 5-34.

Norton, S.W., Tomal, A., 2009. Religion and female educational attainment. Journal of Money, Credit and Banking 41, 961-986.

Papaioannou, E., Siourounis, G., 2008. Economic and social factors driving the third wave of democratization. Journal of Comparative Economics 36 , 365-387.

Schultz, T., 1994. Human capital investment in women and men: micro and macro evidence of economic returns. Occasional Paper 44. International Centre on Economic Growth, San Francisco CA.

Schultz, T., 2002. Why governments should invest more to educate girls. World Development 30, 207-225.

Summers, R., Heston, A., 1991. The Penn World Table (Mark 5): an expanded set of international comparisons, 1950-1988. Quarterly Journal of Economics 106, 327-368.

The Encyclopaedia of World Geography, 1994. In: Bateman, G., Egan, V. (Eds.), Andromeda Oxford Limited, Oxford, U.K.

Tsai, M.-C., 2006. Does political democracy enhance human development in developing countries? American Journal of Economics and Sociology 65, 233-268.

United Nations, 2008. Millennium development goals. http://www.unmillenniumproject.or/goals2008downloaded February 2008.

Vreeland, J., 2008. The effect of political regime on civil war: unpacking anocracy. Journal of Conflict Resolution 52, 401-425.

Waylen, G., 1994. Women and democratization - conceptualizing gender relations in transition politics. World Politics 46, 327-354.

Welzman, Y., 2010. Development failure and the failure of democracy. Chapter 3 in: The Persistence of Ineffective Aid. PhD thesis, Bar-Ilan University.

World Bank, 2010. World Development Indicators. Washington, D. C. 